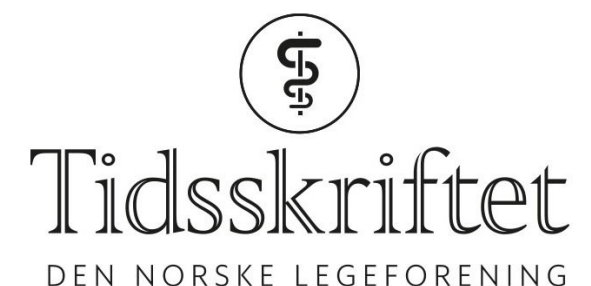

DEN NORSKE LEGEFORENING

\title{
Laboratoriet er helsevesenets hjerte
}

LEDER

\section{HANNE ELISABETH AKSELSEN}

E-post: hanaks@ous-hf.no

Hanne Elisabeth Akselsen er bioingeniør og leder for fag og kvalitet i Klinikk for laboratoriemedisin ved Oslo universitetssykehus.

Laboratoriefagene er vant til å være i bakgrunnen, men i mars 2020 ble de med ett veldig synlige.

Fredag før påske i fjor fikk Klinikk for laboratoriemedisin ved Oslo universitetssykehus (OUS) et viktig oppdrag: Laboratoriet skulle øke testkapasiteten for SARS-CoV-2 fra 1500 til 10 ooo analyser per døgn. Dette høykapasitetslaboratoriet skulle bistå med SARS-CoV-2testing, og dermed bidra til raskere smittesporing, raskere avklaring av sykdomsstatus og dermed bedre behandlingsmuligheter. Høyere testkapasitet og raskere svar kunne også bidra til kortere karantenetid og dermed lavere sykefravær hos arbeidstakere.

Det hastet med å finne kvalifisert personell, identifisere arealer, etablere infrastruktur og gå til innkjøp av nytt utstyr og reagenser. Pandemilaben ble etablert med pipetteringsroboter, PCR-instrumenter og med hjelp av en innovativ protokoll for RNA-ekstraksjon basert på magnetiske kuler utarbeidet ved NTNU (1). Ekstraksjon med magnetiske kuler er en velkjent metode for isolering av DNA og RNA fra virus. NTNU bruker mindre partikler enn det som er kjent fra før: magnetiske nanopartikler. NTNU-reagensen var helt avgjørende for at prosjektet skulle lykkes. Avdeling for mikrobiologi bidro med en egenutviklet, validert PCRtest basert på en metode distribuert fra Corman i Berlin, ofte referert til som Berlinprotokollen (2).

Det var få som trodde det var mulig å etablere et slikt høykapasitetslaboratorium, men etter krevende utviklingsarbeid kunne Pandemilaben stolt åpne for analysering av de første covid-19-pasientprøvene 27. mai 2020. Den 11. mars 2021 nådde Pandemilaben sin høyeste svarutgivelse med 11263 analyser per døgn. Til sammenlikning kan den største plattformen for klamydia, gonore og mykoplasma ved Oslo universitetssykehus analysere 50 ooo prøver i året, og ved en influensaepidemi er kapasiteten ca. 300 prøver per dag.

Kravet om stadig kortere svartider førte til at vi allerede i april 2020 etablerte et tilbud om PCR-basert hurtigdiagnostikk til utvalgte pasientgrupper. Disse testene brukes primært på inneliggende pasienter ved Oslo universitetssykehus. Hurtigdiagnostikk ble også raskt etablert på de andre mikrobiologiske laboratoriene i Norge.

Pandemien har lært oss viktigheten av å være tilpasningsdyktige. Viruset vi trodde vi hadde lært oss å kjenne muterte til nye, mer smittsomme varianter

Hurtigtesten tar en drøy time fra den ankommer laboratoriet, og den raske svartiden er 
testens viktigste fortrinn. Begrensningen er at man kun kan analysere en prøve om gangen. Til sammenligning er svartiden for en poliklinisk prøve etter ankomst i pandemilaben ca. fire timer, men da analyseres zoo prøver samtidig.

Pandemien har lært oss viktigheten av å være tilpasningsdyktige. Viruset vi trodde vi hadde lært oss å kjenne muterte til nye, mer smittsomme varianter. Sekvensering av virusgenomet ble aktualisert i nyhetsbildet hvor vi alle lærte om «britiske», «sørafrikanske» og «brasilianske» virusvarianter (3-6). Da det ble klart at FHIs referanselaboratorium ikke hadde tilstrekkelig kapasitet til å håndtere den $ø$ kte etterspørselen etter covidsekvensering (7), fikk Klinikk for laboratoriemedisin ved Oslo universitetssykehus igjen en forespørsel om å bidra.

Avdeling for medisinsk genetikk (OUS) leder den nasjonale forskningsinfrastrukturen for DNA-sekvensering i Norge. På rekordtid ble covidsekvensering etablert som metode gjennom et samarbeid mellom avdeling for medisinsk genetikk og avdeling for mikrobiologi. Via den nasjonale forskningsinfrastrukturen for DNA-sekvensering - Norsk konsortium for sekvensering og persontilpasset medisin (NorSeq) (8)-ble metoden også eksportert til NorSeq-noder i Bergen, Trondheim og Troms $ø$. Per i dag sekvenseres gjennomsnittlig 700 virusprøver ukentlig ved Oslo universitetssykehus, og antallet prøver kan uten store problemer dobles dersom behovet oppstår.

Testkapasiteten i Europa (9) er god. I vestlige land brukes sekvensering aktivt for å overvåke nye mutasjoner som oppstår. I den tredje verden er testkapasiteten veldig varierende og de færreste blir testet. De fleste diagnostiseres ut ifra symptomer.

Laboratoriemedisinen er en bærebjelke i vårt moderne helsevesen

Den britiske koronamutasjonen (4) med Lineage B.1.1.7 var en av de første variantene av SARS CoV-2 hvor en mutasjon i virusmembranen øker graden av smittsomhet. Den ble først oppdaget i Storbritannia oktober 2020 og spredde seg raskt i hele Europa. I Europa og Norge har dette blitt den dominerende varianten, og ved Oslo universitetssykehus utgjør denne varianten nå ca. $100 \%$ av de positive prøvene. I India er det nå «Indiavarianten» Lineage B.1.617 som er helt dominerende. På Oslo universitetssykehus har vi per 26.5.2021 påvist sju tilfeller.

Klinikk for laboratoriemedisin deltar med stor iver i laboratoriedugnaden sammen med de andre helseforetakene. Vi har alle et felles mål, nemlig å tilby høy testkapasitet og levere raske og kvalitetssikrete svar for å ha kontroll på antall smittetilfeller og påfølgende smittesporing. I motsetning til i mars 2020 har vi nå oversikt over smittesituasjonen - en direkte følge av ny og forbedret diagnostikk. Enhver lege i akuttmottak vet hvor viktig laboratoriediagnostikken er for å kunne ta informerte behandlingsvalg. Laboratoriemedisinen er en bærebjelke i vårt moderne helsevesen. Men det er først når vi mangler laboratoriediagnostiske tilbud - som i pandemiens første fase - at vi tenker over hvor viktig god laboratoriediagnostikk er.

\section{LITTERATUR:}

1. Norges teknisk-naturvitenskaplige universitet. NTNU COVID-19 test.

https://www.ntnu.edu/ntnu-covid-19-test/ Lest 7.4.2021.

2. Corman VM, Landt O, Kaiser M et al. Detection of 2019 novel coronavirus (2019-nCoV) by real-time RT-PCR. Euro Surveill 2020; 25: 2000045. [PubMed][CrossRef]

3. Leung K, Shum MH, Leung GM et al. Early transmissibility assessment of the N501Y mutant strains of SARS-CoV-2 in the United Kingdom, October to November 2020. Euro Surveill 2021; 26: 2002106.

[PubMed][CrossRef]

4. Davies NG, Abbott S, Barnard RC et al. Estimated transmissibility and impact of SARS-CoV-2 lineage B.1.1.7 in England. Science 2021; 372: eabg3055. [PubMed][CrossRef] 
5. Sabino EC, Buss LF, Carvalho MPS et al. Resurgence of COVID-19 in Manaus, Brazil, despite high seroprevalence. Lancet 2021;397: 452-5. [PubMed][CrossRef]

6. Vogels CBF, Breban MI, Alpert T et al. PCR assay to enhance global surveillance for SARS-CoV-2 variants of concern. MedRxiv. Preprint 12.3.2021. https://doi.org/10.1101/2021.01.28.21250486 Lest 7.4.2021.

7. Oude Munnink BB, Nieuwenhuijse DF, Stein M et al. Rapid SARS-CoV-2 whole-genome sequencing and analysis for informed public health decision-making in the Netherlands. Nat Med 2020; 26: 1405-10. [PubMed][CrossRef]

8. The Norwegian Consortium for Sequencing and Personalized Medicine. https://www.norseq.org/ Lest 18.5.2021.

9. European Centre for Disease Prevention and Control.

https://www.ecdc.europa.eu/en/geographical-distribution-2019-ncov-cases/ Lest 18.5.2021.

Publisert: 7. juni 2021. Tidsskr Nor Legeforen. DOI:10.4045/tidsskr.21.0439

(C) Tidsskrift for Den norske legeforening 2020. Lastet ned fra tidsskriftet.no 